\title{
Organic residues on rooting and yield of sugarcane in Typic Quartzipsamments soil
}

\author{
José C. Pina ${ }^{1}$, José A. M. Bono ${ }^{1}$, Ademir K. M. de Oliveira ${ }^{1}$, Rodrigo dos S. Rufino ${ }^{2} \&$ Diogo O. Amorim ${ }^{2}$ \\ ${ }^{1}$ Programa de Pós-Graduação em Meio Ambiente e Desenvolvimento Regional/Universidade Anhanguera-Uniderp. Campo Grande, MS. E-mail: \\ josecarlos_pina@yahoo.com.br; bono@uniderp.edu.br; akmorbeckoliveira@gmail.com (Autor correspondente) \\ ${ }^{2}$ Campus Agrárias/Universidade Anhanguera-Uniderp. Campo Grande, MS. E-mail: rodrigorufino@rocketmail.com; diogoamorimrn@hotmail.com
}

\section{Key words:}

Saccharum officinarum

sustainability

renewable residues

yield

\begin{abstract}
A B S T R A C T
The use of renewable residues as a source of nutrients, associated with chemical input, can provide better efficiency, greater amount of nutrients available to the plant and reduce its application. The objective of this study was to evaluate the influence of different organic residues associated with chemical fertilizer (NPK) on sugarcane rooting and yield. The experiment was conducted in a Typic Quartzipsamments soil, located in Campo GrandeMS, Brazil, from October 2010 to September 2013. The plots were 4 x $5 \mathrm{~m}\left(20 \mathrm{~m}^{2}\right)$, set in a randomized block design with four replicates. The treatments consisted of poultry litter $\left(10 \mathrm{tha}^{-1}\right)$, filter cake $\left(10 \mathrm{tha}^{-1}\right)$, vermicompost $\left(10 \mathrm{tha}^{-1}\right)$ and vinasse $\left(300 \mathrm{~m}^{3} \mathrm{ha}^{-1}\right)$, all associated with basic NPK fertilizer, and control (only basic fertilization). All sources were applied in the furrows before planting, with the exception of vinasse, which was applied through fertigation. The results showed that treatment with filter cake obtained the highest amount of roots with yield gain in the $1^{\text {st }}$ and $2^{\text {nd }}$ harvests.
\end{abstract}

\section{Palavras-chave: Saccharum officinarum sustentabilidade resíduos renováveis produtividade}

\section{Resíduos orgânicos no enraizamento e produtividade da cultura de cana-de-açúcar em solo Neossolo Quartzarênico órtico}

\begin{abstract}
R E S U M O
Associada ao insumo químico, a utilização de resíduos renováveis como fonte de nutrientes pode proporcionar melhor eficiência do mesmo, disponibilizando maior quantidade de nutrientes à planta, além de reduzir as quantidades aplicadas. O objetivo deste trabalho foi avaliar a influência de diferentes resíduos orgânicos associados a um fertilizante químico (NPK) no enraizamento e na produtividade da cana-de-açúcar. O experimento foi conduzido em solo classificado como Neossolo Quartzarênico órtico em área localizada no município de Campo Grande, Mato Grosso do Sul, de outubro de 2010 a setembro de 2013. As parcelas experimentais foram de $4 \times 5 \mathrm{~m}\left(20 \mathrm{~m}^{2}\right)$ e os tratamentos constituídos por cama de frango $\left(10 \mathrm{tha}^{-1}\right)$, torta de filtro $\left(10 \mathrm{t} \mathrm{ha}^{-1}\right)$, vermicomposto $\left(10 \mathrm{t} \mathrm{ha}^{-1}\right)$ e vinhaça $\left(300 \mathrm{~m}^{3} \mathrm{ha}^{-1}\right)$ associados à adubação básica de NPK e testemunha (somente a adubação básica). Todas as fontes foram aplicadas nos sulcos antes do plantio, com exceção da vinhaça, através de fertirrigação. O delineamento foi em blocos ao acaso, com quatro repetições. Nos resultados observou-se que o tratamento com torta de filtro obteve a maior quantidade de raízes refletindo, assim, em ganho de produtividade, tanto no $1^{\circ}$ como no $2^{\circ}$ corte.
\end{abstract}




\section{INTRODUCTION}

Sugarcane (Saccharum officinarum L.) is seen by the scientific community as the most viable option in terms of biofuels, in order to reduce $\mathrm{CO}_{2}$ emissions gradually, and Brazil occupies a prominent position in the production of sugar and ethanol (UNICA, 2013). In the state of Mato Grosso do Sul, the sugarcane area increased from 136.000 to more than 360.000 ha in the last six years. In the expansion of agricultural areas for sugarcane, it is essential to consider the requirements of the crop with respect to the soil types and, if necessary, make the soil physically and chemically adequate (Staut, 2006).

The high costs of agricultural inputs, combined with the increasing concern regarding water and atmosphere pollution caused by the indiscriminate use of fertilizers, stimulates the search for alternative fertilization sources that allow total or partial replacement of mineral fertilizers (Scivittaro et al., 2000), and the use of residues of other activities is one of the alternative sources.

According to Torres et al. (2012), the various byproducts obtained in industrial production of sugar and alcohol can be used in different ways, including as fertilizers, providing considerable economy in fertilization and lower environmental impact.

The use of residues from the sugar and alcohol industry and the practice of maintaining those in the soil as fertilizers can partially solve some problems generated by residue disposal, in benefit of the sustainability of the production.

The generation of residues from the agricultural industries in Brazil was estimated to be around 290,838,411 t for 2009, of which bagasse and filter cake constituted nearly $70 \%$. Vinasse contributed with a volume of liquid effluent of $604,255,461 \mathrm{~m}^{3}$ year $^{-1}$ (PNRS, 2011).

Laime et al. (2011) report that vinasse can irrigate and, at the same time, fertilize crops, which is why it provides the double benefit of disposal and input economy, when it decreases the costs with chemical fertilizers.

The use of filter cake as a substitute for traditional phosphorus-based agricultural inputs, especially in planting, has increased. Filter cake is no longer a residue and has become an organic byproduct used by the sugar and alcohol industry to recover nutrient-deficient soils. Besides containing properties of correction of soil acidity, it also has high water retention capacity (Fravet et al., 2010).

Another residue source is related to the technological advance of the Brazilian animal production. Considering only poultry, pig and dairy cattle (predominantly confined and semi-confined) farming, a total residue production of 365,315,261 t year-1 was estimated for 2009 (PNRS, 2011), which must be adequately disposed.

According to Santos et al. (2010), the use of organic residues produced by animal activity as a source of nutrients for plants and as soil conditioner has become a viable alternative in terms of environmental preservation, reducing significantly the application of chemical fertilizers and minimizing the contamination of the environment. In addition, the supply of raw material in a long term and at a low cost is guaranteed.

The residues from intensive poultry farming, called poultry litter, are rich in nutrients and can increase crop yield, as reported by Costa et al. (2009) and Felini \& Bono (2011). Since these residues are available in the properties at a low cost, they can be provided by the farmers for the fertilization of crops; however, if used incorrectly, they can become an environmental contaminant (Kelleher et al., 2002).

Another option for the correct disposal of organic residues is through vermicomposting. The vermicompost is the result of the alteration of organic matter residues by earthworms and has been extensively studied for containing alkaline humifying microorganisms and bacteria (Souza et al., 2006). According to Steffen et al. (2010), cattle manure has been the most used raw material and earthworm excrements are rich in nutrients, especially $\mathrm{N}, \mathrm{Ca}, \mathrm{P}, \mathrm{Mg}$ and $\mathrm{K}$, showing optimal cation exchange capacity and high organic matter content.

From the perspective of sustainability of the production systems, the application of organic residues, only as a way to reestablish nutrient balance in the soil has become a less important function, since one of the desired goals is the synchrony between nutrient release and plant needs (Silva et al., 2008).

A few studies have been conducted by the breeding programs with respect to root development, despite its importance, with significant lack of research results on this subject in the world, due to the methodological difficulties, inaccessibility to the root system as an object of experimentation, high variability and the time necessary for root quantification, besides the uncertainties of the results (Zonta et al., 2006).

This study aimed to evaluate the influence of different organic residues associated with chemical fertilizers on sugarcane rooting and yield, in a soil classified as Typic Quartzipsamments, in Campo Grande-MS, Brazil.

\section{Material ANd Methods}

The study was carried out in a Typic Quartzipsamments soil (Quartz Sand), located in the municipality of Campo GrandeMS, Brazil, at the Agriculture Campus of the Anhanguera University-Uniderp (20²8' 40” S; 54 40’32” W).

According to the classification of Köppen-Geiger, the climate of Campo Grande is between the subtypes Cfa, which is humid mesothermal without drought period or with a short drought period, and Aw, which is tropical humid with rainy, hot season in the summer and dry season in the winter. The mean annual rainfall is $1,430.1 \mathrm{~mm}$ and the mean annual temperature is $22.7^{\circ} \mathrm{C}$ (CPTEC-INPE, 2014).

The soil of the experimental area was heavily harrowed and leveled before opening the planting furrows. Soil samples were collected (Table 1) before soil preparation and treatment application, and subjected to the analytical procedures to determine the following parameters: $\mathrm{pH}$ in water and $\mathrm{CaCl}_{2}$ (potentiometry), available $\mathrm{P}$ (Mehlich), exchangeable $\mathrm{K}+$ (flame photometry), $\mathrm{Ca}$ and $\mathrm{Mg}$ (titration) and organic matter (colorimetry), according to EMBRAPA (2009). For the physical analysis, the pipette method was used (Veiga, 2011).

Three months before planting, $2 \mathrm{t} \mathrm{ha}^{-1}$ of dolomitic limestone effective calcium cabonate equivalence (ECCE) of $85 \%$ were broadcast and incorporated in the layer of $0-0.20$ $\mathrm{m}$. According to the soil analysis, a basal fertilization of 200 
Table 1. Chemical and physical characteristics of the soil in the experimental area, for the layers of $0-0.10$ and $0.10-0.20 \mathrm{~m}$

\begin{tabular}{lcc}
\hline \multirow{2}{*}{ Attribute } & $\mathbf{0 - 0 . 1}$ & $\mathbf{0 . 1 - 0 . 2}$ \\
\cline { 2 - 3 } $\mathrm{pH}$ in water & \multicolumn{2}{c}{$\mathrm{m}$} \\
$\mathrm{pH} \mathrm{CaCl}$ & 6.1 & 5.2 \\
Assimilable phosphorus $\left(\mathrm{mg} \mathrm{dm}^{-3}\right)$ & 5.5 & 4.8 \\
Potassium $\left(\mathrm{mg} \mathrm{dm}^{-3}\right)$ & 15 & 2 \\
\hline Exchangeable calcium $\left(\mathrm{cmol}_{+} \mathrm{dm}^{-3}\right)$ & 40 & 28 \\
Exchangeable magnesium $\left(\mathrm{cmol}_{+} \mathrm{dm}^{-3}\right)$ & 2.4 & 1.1 \\
Exchangeable aluminum $\left(\mathrm{cmol}_{+} \mathrm{dm}^{-3}\right)$ & 1.2 & 0.6 \\
Hydrogen + Aluminum $\left(\mathrm{cmol}_{+} \mathrm{dm}^{-3}\right)$ & 0.0 & 0.3 \\
Sum of bases $\left(\mathrm{cmol}_{+} \mathrm{dm}^{-3}\right)$ & 2.7 & 2.4 \\
Cation exchange capacity $\left(\mathrm{cmol}_{+} \mathrm{dm}^{-3}\right)$ & 3.7 & 1.8 \\
Base saturation $(\%)$ & 6.4 & 4.2 \\
Aluminum saturation $(\%)$ & 58 & 43 \\
Organic matter $\left(\mathrm{g} \mathrm{dm}^{-3}\right)$ & 0.0 & 14 \\
Clay (\%) & 20.1 & 16.5 \\
Silt (\%) & 12 & 13 \\
Fine sand (\%) & 4 & 4 \\
Medium sand (\%) & 74 & 73 \\
Coarse sand (\%) & 8 & 7 \\
\hline
\end{tabular}

$\mathrm{kg} \mathrm{ha}^{-1}$ of $\mathrm{P}_{2} \mathrm{O}_{5}$ (single superphosphate) and $80 \mathrm{~kg} \mathrm{ha}^{-1}$ of $\mathrm{K}_{2} \mathrm{O}$ (potassium chloride) was applied in the planting furrow.

Clone material of the sugarcane variety RB-72-454 was manually planted in October 2010, in furrows, with density of 10 buds $\mathrm{m}^{-1}$, at a depth of $0.20 \mathrm{~m}$. The $0.25 \mathrm{~m}$ deep furrows were opened with a furrower and were $1.46 \mathrm{~m}$ apart.

At 60 days after planting $60 \mathrm{~kg} \mathrm{ha}^{-1}$ of $\mathrm{N}$ (urea) and $60 \mathrm{~kg}$ ha $^{-1}$ of $\mathrm{K}_{2} \mathrm{O}$ (potassium chloride) were applied as topdressing along the planting row, $0.20 \mathrm{~m}$ distant from the plants. After each cut, maintenance fertilization was performed using $100 \mathrm{~kg}$ $\mathrm{ha}^{-1}$ of $\mathrm{N}$ (urea) and $100 \mathrm{~kg} \mathrm{ha}^{-1}$ of $\mathrm{K}_{2} \mathrm{O}$ (potassium chloride). Basal, topdressing and maintenance fertilizations constituted the basic NPK fertilization for all the experimental treatments.

The treatments constituted of poultry litter $\left(10 \mathrm{t} \mathrm{ha}^{-1}\right)$, filter cake $\left(10 \mathrm{tha}^{-1}\right)$, vermicompost $\left(10 \mathrm{tha}^{-1}\right)$, vinasse (300 $\mathrm{m}^{3} \mathrm{ha}^{-1}$ ), associated with the basic NPK fertilization, and a control treatment (only basic fertilization). All the sources were applied in the planting furrows before planting, except for vinasse, which was applied by fertigation after planting, using a watering can with a perforated nozzle, in a controlled way in order to avoid surface runoff. Five treatments were distributed in the field in a randomized block design, with four replicates, and the experimental plots were composed of four $5 \mathrm{~m}$ long, $1.46 \mathrm{~m}$ apart sugarcane rows $(4 \times 5 \mathrm{~m})$.

The first cut was performed in October 2011 and the second in September 2013, in order to evaluate stem yield. Also in September, soil samples were collected in the layers of 0-0.10 and $0.10-0.20 \mathrm{~m}$, in the rows and interrows, and the material was sent to the soil laboratory for analysis.

For yield evaluation, in the experimental area inside each plot $\left(2 \mathrm{~m}^{2}\right)$, stems were cut close to the soil surface and the tops were eliminated. After weighing in a mechanical scale, the data were converted to $t \mathrm{ha}^{-1}$.

In order to analyse root production, blocks $(0.10 \times 0.10 \mathrm{x}$ $0.10 \mathrm{~m}$ ) of undisturbed soil containing roots were collected in the rows and interrows, in the different layers, according to the adapted methodology of Veiga (2011).
The blocks were weighed and a $100 \mathrm{~g}$ subsample was collected and dried at $105^{\circ} \mathrm{C}$ in a forced-air oven, in order to obtain the soil water content. Then, soil and root dry weights were obtained using this value.

The soil samples were dried in the shade, and soil and roots were separated using a stainless steel sieve ( $2 \mathrm{~mm}$ grid). After this, the roots were dried at $65^{\circ} \mathrm{C}$ in a forced-air oven, weighed and the weights were converted to $\mathrm{tha}^{-1}$.

Root dry weight was calculated based on the values of soil and root dry weights in the samples and extrapolated to $\mathrm{tha}^{-1}$.

The data were subjected to analysis of variance using the software SAS and the GLM procedures and, when significant, Tukey test at 0.05 probability level was applied to compare treatment means.

\section{Results AND Discussion}

In general, the renewable residues, whose inadequate disposal could cause environmental impacts, promoted favorable effects when added during soil preparation, influencing sugarcane yield positively in comparison to the control treatment, with only basic fertilization, contributing with a higher stem yield.

The incorporation of different types of organic matter $(\mathrm{OM})$ associated with the basic fertilization allowed higher nutrient supply for the crop, and possibly a more efficient water retention. According to Bayer \& Mielniczuk (2008), the main soil physical characteristic affected by the addition of organic matter is aggregation, influencing directly the other properties, such as bulk density, porosity, aeration, retention capacity and water infiltration, which are essential for the productive capacity of the soil.

Evaluating the initial nutrient availability in the soil (Table 1), it can be verified that phosphorus $(\mathrm{P})$ contents increased in all the evaluated treatments (Table 2), even in the control. The observed content of available $\mathrm{P}$ is higher than the one found in the initial analysis, due to the application of NPK from the basic fertilization in planting and the maintenance fertilization after each cut. According to Machado et al. (2011), it is necessary to adapt the application of phosphate fertilizers according to the soil type, since each textural class has a different behavior in relation to $\mathrm{P}$ adsorption and availability. As the nutrient remains in contact with the sandy soil, there is a tendency for higher availability, since the adsorption is lower because of the low clay percentage.

However, the highest $\mathrm{P}$ content was always found in the layer of $0-0.10 \mathrm{~m}$, in the row, which indicates that this is the most adequate layer for root development. All treatments showed statistically similar P contents, in rows and interrows for the layer of $0-0.10 \mathrm{~m}$, except the control. For the layer of $0.10-0.20 \mathrm{~m}$, the treatments control and vinasse, in the rows, and filter cake, in the interrows, showed lower P contents compared with the others.

In sugarcane, $\mathrm{P}$ plays an important role in rooting and tillering and, therefore, in the final productivity and sugar yield (Santos et al., 2011), which highlights the importance of this study. 
After the first soil analysis (Table 1), all treatments with the addition of OM showed increase in potassium $(\mathrm{K})$ contents (Table 2). In the control treatment, where no OM was applied, there was a decrease. According to Rosolem et al. (2006), OM increases the amount of $\mathrm{K}$ in the soil, decreasing its leaching in the profile, with the change from exchangeable $\mathrm{K}$ to nonexchangeable $\mathrm{K}$, which can be fast with the increase of the residual effect, influencing the leaching process.

The highest $\mathrm{K}$ content was also observed in the layer of 0-0.10 m, in the row. Except for the control, all the treatments showed statistically similar results, indicating that the addition of any of the residues promotes the same content of nutrients.

The element calcium $(\mathrm{Ca})$ showed the greatest variation for the treatments, probably due to its chemical form in the different residues. For the treatments filter cake, vinasse, vermicompost and control, the highest $\mathrm{Ca}$ contents were observed in the interrows, in the layer of $0-0.10 \mathrm{~m}$, and for poultry litter, in the rows for the layer of $0.10-0.20 \mathrm{~m}$. The treatments filter cake, poultry litter and vermicompost, in the row, for the layer of $0-0.10 \mathrm{~m}$, and filter cake, poultry litter, vinasse and vermicompost promoted the same Ca contents, indicating that all residues are adequate to supply plants with Ca.

The statistical results confirmed that the addition of residues was benefitial to the crop, with significant interaction $(\mathrm{p}<0.01)$ for treatments and sampling sites (rows and interrows) in the increase of nutrients.

All the treatments showed the highest OM contents in the layer of $0-0.10 \mathrm{~m}$, in the row, followed by the layer of 0.10 $0.20 \mathrm{~m}$ in the row, while the interrows showed the lowest OM contents for all the treatments (Table 3). The highest OM content was observed in the treatment poultry litter, in the row, for the layer of $0-0.10 \mathrm{~m}$, which was statistically superior to the others. These results agree with Passos et al. (2007), who found that the type of fertilization influences OM contents in the soil. The highest OM contents in the row, compared with the interrows, must be attributed to the form of application of the residues in the planting furrows, except for vinasse (fertigation). In addition, the fact that sugarcane root system was more developed in the row, in the layer of 0-0.10 m, can have been influenced with the increase in the amount of OM. According to Luz et al. (2009), poultry litter is a good source of nutrients and, when correctly managed, can partially or totally replace the chemical fertilizer; its use adds organic matter, which improves soil physical attributes, increasing water retention capacity and improving soil aeration, besides creating a more adequate environment for the development of the soil microbiota.

Root density decreased in the interrows as depth increased for all the treatments (Table 3), except for poultry litter, in which it increased in the interrows as depth increased.

The highest root yields were observed in the superficial layer $(0-0.10 \mathrm{~m})$, close to the sugarcane plants (Row), showing higher concentration of the root system in this area. The general root density was superior to the control and the treatments filter cake, poultry litter and vermicompost, which were statistically similar in the row, for the layer of 0-0.10 m. Statistically similar were also filter cake and poultry litter for the layer of $0.10-0.20 \mathrm{~m}$ in the row; filter cake, vinasse and vermicompost and for the layer of $0-0.10 \mathrm{~m}$ in the interrows; and filter cake and poultry litter, for the layer of $0.10-0.20 \mathrm{~m}$.

The fertilization with filter cake caused the highest root yield, followed by poultry litter, indicating that these two types of residue are the most adequate to produce the greatest

Table 2. Mean values of available phosphorus in the soil (P), exchangeable potassium (K) and exchangeable calcium (Ca) in the rows and interrows of sugarcane cultivated in a Typic Quartzipsamments soil, with the application of different types of residue

\begin{tabular}{|c|c|c|c|c|c|c|c|}
\hline Variable & & Filter cake & Poultry litter & Vinasse & Vermicompost & Control & Layer (m) \\
\hline \multirow{4}{*}{$\begin{array}{c}P \\
\left(\mathrm{mg} \mathrm{dm}^{-3}\right)\end{array}$} & Row & $73.5 \mathrm{Aa}$ & $64.5 \mathrm{Aa}$ & $48.5 \mathrm{Aa}$ & $68.5 \mathrm{Aa}$ & $28.2 \mathrm{Ca}$ & \multirow{2}{*}{$0-0.10$} \\
\hline & Interrow & $34.5 \mathrm{Ab}$ & $43.7 \mathrm{Ab}$ & 40.4 Aab & $40.2 \mathrm{Abc}$ & $32.5 \mathrm{Aa}$ & \\
\hline & Row & $61.0 \mathrm{Aa}$ & 53.7 Abb & $44.5 \mathrm{Bab}$ & $55.5 \mathrm{Abb}$ & $27.0 \mathrm{Ca}$ & \multirow{2}{*}{$0.10-0.20$} \\
\hline & Interrow & $25.5 \mathrm{Bb}$ & $42.5 \mathrm{Ab}$ & $37.5 \mathrm{Ab}$ & $37.7 \mathrm{Ac}$ & $28.2 \mathrm{Ba}$ & \\
\hline \multirow{4}{*}{$\begin{array}{c}\mathrm{K} \\
\left(\mathrm{mg} \mathrm{dm} \mathbf{~}^{-3}\right)\end{array}$} & Row & $80 \mathrm{Aa}$ & $92 \mathrm{Aa}$ & $67 \mathrm{Aa}$ & $74 \mathrm{Aa}$ & $27 \mathrm{Bab}$ & \multirow[b]{2}{*}{$0-0.10$} \\
\hline & Interrow & $41 \mathrm{Abc}$ & $39 \mathrm{Ac}$ & $48 \mathrm{Ab}$ & $43 \mathrm{Ac}$ & $31 \mathrm{Ba}$ & \\
\hline & Row & $47 \mathrm{Ab}$ & $58 \mathrm{Ab}$ & $46 \mathrm{Ab}$ & $55 \mathrm{Ab}$ & $19 \mathrm{Bb}$ & \multirow{2}{*}{$0.10-0.20$} \\
\hline & Interrow & $31 \mathrm{Abc}$ & $35 \mathrm{Abc}$ & $31 \mathrm{ABC}$ & $41 \mathrm{AC}$ & $27 \mathrm{Bab}$ & \\
\hline \multirow{4}{*}{$\begin{array}{c}\mathrm{Ca} \\
\left(\mathrm{cmol}^{+} \mathrm{dm}^{-3}\right)\end{array}$} & Row & $2.2 \mathrm{Aa}$ & $3.2 \mathrm{Aa}$ & $1.4 \mathrm{Ba}$ & $2.3 \mathrm{Aa}$ & $1.3 \mathrm{Ba}$ & \multirow{2}{*}{$0-0.10$} \\
\hline & Interrow & $3.0 \mathrm{Aa}$ & $2.6 \mathrm{Aa}$ & $2.1 \mathrm{Aba}$ & $3.5 \mathrm{Aa}$ & $1.2 \mathrm{Ba}$ & \\
\hline & Row & $1.4 \mathrm{Ba}$ & $3.7 \mathrm{Aa}$ & $1.0 \mathrm{Ba}$ & $1.1 \mathrm{Bb}$ & $0.8 \mathrm{Ba}$ & \multirow{2}{*}{$0.10-0.20$} \\
\hline & Interrow & $2.8 \mathrm{Aa}$ & $2.9 \mathrm{Aa}$ & $1.4 \mathrm{Ba}$ & $2.2 \mathrm{Aba}$ & $0.7 \mathrm{Ba}$ & \\
\hline
\end{tabular}

Means followed by the same letters, uppercase in the row and lowercase in the column, do not differ by Tukey test at 0.05 probability level

Table 3. Mean values of soil organic matter (OM) and root yield (Root) in rows and interrows of sugarcane cultivated in Typic Quartzipsamments soil with the application of different types of residues

\begin{tabular}{clcccccc}
\hline Variable & & Filter Cake & Poultry Litter & Vinasse & Vermicompost & Control & Layer (m) \\
& Row & $20.1 \mathrm{Ba}$ & $23 \mathrm{Aa}$ & $20 \mathrm{Ba}$ & $21.1 \mathrm{Ba}$ & $15.9 \mathrm{Ca}$ & $0-0.10$ \\
OM & Interrow & $16 \mathrm{Bb}$ & $18 \mathrm{Ab}$ & $16.7 \mathrm{Bb}$ & $17.3 \mathrm{ABb}$ & $12.4 \mathrm{Cb}$ & \\
$\left(\mathrm{g} \mathrm{dm}^{-3}\right)$ & Row & $16 \mathrm{Ba}$ & $19 \mathrm{Aa}$ & $17 \mathrm{Aba}$ & $17.9 \mathrm{Aba}$ & $12.8 \mathrm{Ca}$ & $0.10-0.20$ \\
& Interrow & $15 \mathrm{ABa}$ & $16 \mathrm{Ab}$ & $15 \mathrm{ABb}$ & $14.6 \mathrm{Bb}$ & $11.7 \mathrm{Ca}$ & \\
& Row & $6.9 \mathrm{Aa}$ & $6.0 \mathrm{Aa}$ & $4.1 \mathrm{Ba}$ & $5.2 \mathrm{Aba}$ & $2.4 \mathrm{Ca}$ & $0-0.10$ \\
Root & Interrow & $3.2 \mathrm{Ab}$ & $2.5 \mathrm{Bb}$ & $3.6 \mathrm{Aa}$ & $2.9 \mathrm{ABb}$ & $2.1 \mathrm{Ba}$ & \\
$\left(\mathrm{t} \mathrm{ha}^{-1}\right)$ & Row & $5.4 \mathrm{Aa}$ & $5.1 \mathrm{Aa}$ & $3.4 \mathrm{Ba}$ & $2.6 \mathrm{Ba}$ & $1.0 \mathrm{Ca}$ & $0.10-0.20$ \\
& Interrow & $3 \mathrm{ABb}$ & $4.0 \mathrm{Ab}$ & $2.1 \mathrm{Ba}$ & $2.4 \mathrm{Ba}$ & $0.9 \mathrm{Ca}$ & \\
\hline
\end{tabular}

Means followed by the same letters, uppercase in the row and lowercase in the column, do not differ by Tukey test at 0.05 probability level 
Table 4. Mean values of stem yield ( $\mathrm{tha}^{-1}$ ) of sugarcane cultivated in Typic Quartzipsamments soil with the application of different types of residue

\begin{tabular}{lccc}
\hline \multicolumn{1}{c}{ Treatment } & $\mathbf{1}^{\mathbf{0}}$ cut & $\mathbf{2}^{\mathbf{0}}$ cut & Total \\
Filter cake & $178.1 \mathrm{Ab}$ & $100.7 \mathrm{Ab}$ & $278.8 \mathrm{~A}$ \\
Poultry litter & $170.1 \mathrm{Aa}$ & $86.4 \mathrm{Ab}$ & $256.6 \mathrm{~B}$ \\
Vinasse & $88.9 \mathrm{Ba}$ & $62.4 \mathrm{Ba}$ & $151.3 \mathrm{E}$ \\
Vermicompost & $133.5 \mathrm{ABa}$ & $100.7 \mathrm{Ab}$ & $234.2 \mathrm{C}$ \\
Control & $102.2 \mathrm{Ba}$ & $69.6 \mathrm{Bb}$ & $171.2 \mathrm{D}$ \\
\hline
\end{tabular}

Means followed by the same letters, uppercase in the column and lowercase in the row, do not differ by Tukey test at 0.05 probability level

concentration of roots and, consequently, the highest amount of fresh matter (stems) (Table 4).

The stem yields at the first and second cuts were statistically similar for the treatments filter cake, poultry litter and vermicompost. However, at the end, the treatment filter cake showed the highest total stem yield, followed by poultry litter.

The higher development of the root system in the rows for 0-0.10 $\mathrm{m}$ and $0.10-0.20 \mathrm{~m}$ can have favored the gain in yield for the treatment with filter cake and poultry litter. Fravet et al. (2010), evaluating different doses of filter cake and forms of application (superficial in the rows and incorporated in the interrow), observed higher stem production, regardless of the form of application, also indicating its adequacy for sugarcane fertilization.

According to Anjos et al. (2007), organic fertilization, like filter cake, can replace chemical fertilizers, decreasing both costs and environmental impacts. Silva et al. (2011) also point to the use of poultry litter for fertilization, increasing maize yield, and to its superiority in comparison to mineral fertilizers.

The lower yield for the treatments poultry litter and vermicompost is related to the decrease in stem yield from the first to the second cut, similarly to what occurred for the control. According to Vitti et al. (2007), the sugarcane crop allows various cuts and harvests; however, it is necessary to replant the sugarcane field in order to maintain the yield, which can decrease continuously due to the exhaustion of the soil.

The sharp decrease in yield in the $2^{\circ}$ cut, for the treatment poultry litter, was caused by the use of fresh residue. According to Espíndola et al. (2006), biotic and abiotic factors determine the velocity of the decomposition process and define the persistence of these residues on the soil surface. Thus, the process depends on residue decomposition, soil microbial activity and organic matter content, besides being related to intrinsic and environmental factors, such as rain and temperature, which will influence its efficiency.

It should be pointed out that the treatment using vinasse promoted the lowest stem yield of all the treatments, including the control, with basic fertilization. Since this is an input normally applied in the sugarcane cultivation, it is important to evaluate the reason for such reduction. Barros et al. (2010) claim that only the added amount of vinasse, rich in potassium, is not enough for the nutritional balance of sugarcane in some types of soil, because potassium leaching is a common problem in sandy soils, thus affecting stem yield.

\section{Conclusions}

1. The use of organic residues increased the contents of nutrients and organic matter in the soil, promoting higher root growth.
2. Although the contents of the evaluated nutrients were similar in the soil, the treatment using filter cake promoted the highest final stem yield, and the application in the plant rows is the most recommended for Typic Quartzipsamments soils.

\section{ACKNOWLedgments}

To the Coordination for the Improvement of Higher Education Personnel (CAPES) for granting the scholarship during the period of the Master's degree; to the National Council for Scientific and Technological Development (CNPq) for the productivity scholarship granted to the Anhanguera University-UNIDERP, for funding the GIP project (Interdisciplinary Research Group). Also, thanks to all the people who have supported me during this project.

\section{Literature Cited}

Anjos, I. A.; Andrade, L. A. B.; Garcia, J. C.; Figueiredo, P. A. M.; Carvalho, G. J. Efeitos da adubação orgânica e da época de colheita na qualidade da matéria-prima e nos rendimentos agrícola e de açúcar mascavo artesanal de duas cultivares de cana-de-açúcar (cana-planta). Ciência e Agrotecnologia, v.31, p.59-63, 2007. http://dx.doi.org/10.1590/S1413-70542007000100009

Barros, R. P.; Viégas, P. R. A.; Silva, T. L.; Souza, R. M.; Barbosa, L.; Viégas, R. A.; Barretto, M. C. V.; Melo, A. S. Alterações em atributos químicos de solo cultivado com cana-de-açúcar e adição de vinhaça. Pesquisa Agropecuária Tropical, v.40, p.341-346, 2010. http://dx.doi.org/10.5216/pat.v40i3.6422

Bayer, C.; Mielniczuk, J. Dinâmica e função da matéria orgânica. In: Santos, G. A.; Silva, L. S.; Canellas, L. P.; Camargo, F. A. O. (ed.). Fundamentos da matéria orgânica do solo: ecossistemas tropicais e subtropicais. 2.ed. Porto Alegre: Metrópole, 2008. p.7-18.

Costa, A. M.; Borges, E. N.; Silva, A. A.; Nolla, A.; Guimarães, E. C. Potencial de recuperação física de um Latossolo Vermelho, sob pastagem degradada, influenciado pela aplicação de cama de frango. Ciência e Agrotecnologia, v.33, p.1991-1998, 2009. http:// dx.doi.org/10.1590/S1413-70542009000700050

CPTEC-INPE - Centro de Previsão de Tempo e Estudos ClimáticosInstituto Nacional de Pesquisas Espaciais. Arquivos do Laboratório de Meteorologia e Climatologia, vinculados ao CPTEC-INPE. Campo Grande: CPTEC-INPE, 2014. s.n.p.

EMBRAPA - Empresa Brasileira de Pesquisas Agropecuária. Manual de análises químicas de solos, plantas e fertilizantes. Silva, F. C. (ed.). 2.ed. Brasília: Embrapa Informação Tecnológica, 2009. 627p.

Espíndola, J. A. A.; Guerra, L. G. M.; Almeida, D. L.; Teixeira, M. G.; Urquiaga, S. Decomposição e liberação de nutrientes acumulados em leguminosas herbáceas perenes consorciadas com bananeira. Revista Brasileira de Ciência do Solo, v.30, p.321-328, 2006. http:// dx.doi.org/10.1590/S0100-06832006000200012

Felini, F. Z; Bono, J. A. M. Produtividade de soja e milho, em sistema de plantio com uso de cama de frango na região de Sidrolândia, MS. Ensaios e Ciências - Ciências Agrárias Biológicas e da Saúde, v.15, p.9-18, 2011.

Fravet, P. R. F.; Soares, R. A. B.; Lana, R. M. Q.; Lana, A. M. Q.; Korndörfer, G. H. Efeito de doses de torta de filtro e modo de aplicação sobre a produtividade e qualidade tecnológica da soqueira de cana-de-açúcar. Ciência e Agrotecnologia, v.34, p.618624, 2010. http://dx.doi.org/10.1590/S1413-70542010000300013 
Kelleher, B. P.; Leahy, J. J.; Henihan, A. M.; O’ Dwyer, T. F.; Sutton, D.; Leahy, M. J. Advances in poultry litter disposal technology - A review. Bioresource Technology, v.83, p.27-36, 2002. http://dx.doi. org/10.1016/S0960-8524(01)00133-X

Laime, E. M. O.; Fernandes, P. D.; Oliveira, D. C. S; Freire, E. A. Possibilidades Tecnológicas para a Destinação da Vinhaça: Uma Revisão. Revista Trópica - Ciências Agrárias e Biológicas, v.5, p.16-29, 2011.

Luz, J. M. Q.; Morais, T. P. S.; Blank, A. F.; Sodré, A. C. B.; Guedmiller, S. Teor, rendimento e composição química do óleo essencial de manjericão sob doses de cama de frango. Horticultura Brasileira, v.27, p.349-353, 2009. http://dx.doi.org/10.1590/S010205362009000300016

Machado, V. J.; Souza, C. H. E.; Andrade, B. B.; Lana, R. M.; Korndorfer, G. H. Curvas de disponibilidade de fósforo em solos com diferentes texturas após aplicação de doses crescentes de fosfato monoamônico. BioScience Journal, v.27, p.70-76, 2011.

Passos, R. R.; Ruiz, H. A.; Mendonça, E. S.; Cantarutti, R. B.; Souza, A. P. Substâncias húmicas, atividade microbiana e carbono orgânico lábil em agregados de um Latossolo Vermelho distrófico sob duas coberturas vegetais. Revista Brasileira de Ciência do Solo, v.31, p.1119-1129, 2007. http://dx.doi.org/10.1590/S010006832007000500027

PNRS - Plano Nacional de Resíduos Sólidos. Decreto no 7.404/10, que regulamenta a Política Nacional de Resíduos Sólidos. Brasília: Ministério do Meio Ambiente dos Recursos Hídricos e da Amazônia Legal, 2011. 156p.

Rosolem, C. A.; Santos, F. P.; Foloni, J. S. S.; Calonego, J. C. Potássio no solo em consequência da adubação sobre a palha de milheto e chuva simulada. Pesquisa Agropecuária Brasileira, v.41, p.10331040, 2006. http://dx.doi.org/10.1590/S0100-204X2006000600020

Santos, D. H.; Silva, M. A.; Tiritan, C. S.; Foloni, J. S. S.; Echer, F. R. Qualidade tecnológica da cana-de-açúcar sob adubação com torta de filtro enriquecida com fosfato solúvel. Revista Brasileira de Engenharia Agrícola e Ambiental, v.15, p.443449, 2011.

Santos, J. F.; Grangeiro, J. I. T.; Oliveira, M. E. C. Produção da cultura da mamoneira em função da fertilização com cama de galinha. Engenharia Ambiental, v.7, p.169-180, 2010.
Scivittaro, W. B.; Muraoka, T.; Boaretto, A. E.; Trivelin, P. C. O. Utilização de nitrogênio de adubos verde e mineral pelo milho. Revista Brasileira de Ciências do Solo, v.24, p.917-926, 2000. http://dx.doi.org/10.1590/S0100-06832000000400023

Silva. L. B.; Dick, D. P.; Inda Júnior, A. V. Solos subtropicais de altitude: Características químicas, teor de matéria orgânica e sua resistência à oxidação química. Ciência Rural, v.38, p.1167-1171. 2008. http:// dx.doi.org/10.1590/S0103-84782008000400044

Silva, T. R.; J. F. S; Simon, G. A.; Assis, R. L.; Santos, C. J. L.; Gomes, G. V. Cultivo do milho e disponibilidade de P sob adubação com cama-de-frango. Revista Brasileira de Engenharia Agrícola Ambiental, v.15, p.903-910, 2011.

Souza, L. M.; Castilhos, D. D.; Morselli, T. B. G. A.; Castilhos, R. M. V. Influência da aplicação de diferentes vermicompostos na biomassa microbiana do solo após cultivo de alface. Revista Brasileira de Agrociências, v.12, p.429-434, 2006.

Staut, L. A. Condições dos solos para o cultivo de cana-de-açúcar. 2006. Artigo em Hypertexto. <http://www. infobibos.com/ Artigos/2006_2/CanaSolo/index.htm >. 2 Mai. 2014.

Steffen, G. P. K.; Antoniolli, Z. I.; Steffen, R. B.; Bellé, R. Húmus de esterco bovino e casca de arroz carbonizada como substrato para a produção de mudas de boca-de-leão. Acta Zoológica Mexicana, v.26, p.345-357, 2010.

Torres, N. H.; Sartori, S. B.; Américo, J. H. P.; Ferreira, L. F. R. Indústria sucroalcooleira: gestão de subprodutos. Revista de Ciências AgroAmbientais, v.10, p.225-236, 2012.

ÚNICA - União da Agroindústria Canavieira do Estado de São Paulo. 2013. $<$ http://www.portalunica.com.br/portalunica/?Secao=UNICA\%20 em\%20ação\&SubSecao=cana-de-açúcar $>.1$ Abr. 2013.

Veiga, M. Metodologia para coleta de amostras e análises físicas do solo. Florianópolis: EPAGRI, 2011. 52p. Boletim Técnico, 156.

Vitti, A. C.; Trivelin, P. C. O.; Gava, G. J. C.; Penatti, C. P. P.; Bologna, I. R.; Faroni, C. E.; Franco, H. C. J. Produtividade da cana-de-açúcar relacionada ao nitrogênio residual da adubação e do sistema radicular. Pesquisa Agropecuária Brasileira, v.42, p.249-256, 2007. http://dx.doi.org/10.1590/S0100-204X2007000200014

Zonta, E.; Brasil, F. C.; Goi, S. R.; Rosa, M. M. T. O sistema radicular e suas interações com o ambiente edáfico. In: Fernandes, M. S. (ed.). Nutrição mineral das plantas. Viçosa: Sociedade Brasileira de Ciência do Solo, 2006. p.7-52. 